\title{
CARBON FIBER REINFORCED CERAMIC COMPOSITES
}

\author{
炭素織維強化セラミックス複合材料
}

\author{
$\mathrm{K}$ i $\mathrm{k}$ u \\ Government Industrial Research Institute, Nagoya \\ 1-1, Hirate-cho, Kita-ku, Nagoya, JAPAN \\ TEL:052-911-2111, FAX:052-916-2802 \\ (Recieved 9, November 1990, Accepted 3, December 1990)
}

\begin{abstract}
Unidirectional carbon fiber reinforced $\mathrm{SiC}, \mathrm{B}_{4} \mathrm{C}$ and mullite composites have been fabricated by a process consisting of slurry impregnation followed by hot pressing. Identification of crystal phase and observation of metallographie structures in the composites were carried out. Mechanical properties such as flexural strength and fracture toughness were measured and discussed in connection with the metallographic structures.
\end{abstract}

Key words: carbon fiber, silicon carbide, boron carbide, mullite, composite, fiber reinforcement

\section{Introduction}

Ceramics have excellent characteristics for use in high temperature structural materials and mechanical parts because of their heat-stability, superior strength at high temperatures, and low densities. However they are brittle as monolithic ceramics. The major concern in utilizing ceramics in high temperature structural materials is improving toughness.

Fiber reinforcement has recently been employed in toughening ceramics as a hopeful method. Several processes have been employed for fabricating fiber reinforced ceramics. One example is CVI 1-4), which allows depositing of vapor reactant of ceramic material in the interstices of a preform consisting of a fiber skeleton. Another example is the slurry method 1, 5-9), which allows the formation of a ceramic matrix inside of the preform by the slurry impregnation followed by the sintering either in ordinary pressure or hot pressing.
The CVI method is costly in practice, because it has a long processing time and low yield. However, its reaction temperatures are relatively low, so damage to the fibers are not so severe. The slurry method has a short processing time, but the sintering temperatures are high, so damage to the fibers is unavoidable to some extent.

In the present work the carbon fiber reinforced $\mathrm{SiC}, \mathrm{B}_{4} \mathrm{C}$, and mullite composites were fabricated by the slurry process and the characterization of the composites such as identification of crystal phase, metallographic structure, and mechanical properties was carried out.

\section{Experimental Procedure}

\section{2-1. Fabrication of Composites}

2-1-1. $\mathrm{SiC}$ and $\mathrm{B}_{4} \mathrm{C}$ composites

Two continuous carbon fiber groups the PAN group [ Tohobeslon Besfight ST-3 (high elongation type) and HM40(high modulus type): 
$7 \mu \mathrm{m} \phi$; the structures of these fibers were amorphous-like graphite ] and the pitch group [ PETOCA HM50(high modulus type): 10 $\mu \mathrm{m} \phi$; the crystal structure was crystalline graphite ] were used in this process. Fine powders of $\beta-\mathrm{SiC}$ [ Ibiceram containing $\mathrm{AlB}_{2}$ as a sintering additive (SA): $0.3 \mu \mathrm{m}]$ and $\mathrm{B}_{4} \mathrm{C}$ [ Kyoritsu Yogyo $\mathrm{H}$ type powder $(2.0 \mu \mathrm{m} ; \mathrm{B} / \mathrm{C}=$ 4.1) containing $\mathrm{AlB}_{2}$ as a $\left.\mathrm{SA}\right]$ were used as fillers. An unidirectional fiber aligned prepreg was made by the filament winding method in which a slurry was used. The slurry consisted of filler, a organosilicon resin [ poly-silastyrene (Nihon Soda PSS400) ] and a toluene solvent. The prepreg was cut into segments of equal length $[25 \mathrm{~mm}$ width and $50 \mathrm{~mm}$ length (fiber direction) ] to form post forms. The postforms were isostatically pressed and then pyrolyzed up to $700{ }^{\circ} \mathrm{C}$ in Ar atmosphere. Composite ceramics were made by the hot pressing of pyrolyzed postforms at $1750{ }^{\circ} \mathrm{C}$ and $1800{ }^{\circ} \mathrm{C}$ in the Ar. The process variables used in making the composites are detailed in Table 1.

Table 1.Fabrication Conditions of the Ceramic Composites

\begin{tabular}{|c|c|c|c|c|c|}
\hline Sample No & Matrix of composite & Fiber & Resin & Filler & Hot-pressing temp. $\left({ }^{\circ} \mathrm{C}\right)$ \\
\hline 1 & $\mathrm{SiC}$ & $\operatorname{PAN}(\mathrm{ST}-3)$ & $\begin{array}{l}\text { polysila- } \\
\text { styrene }\end{array}$ & $\beta-\mathrm{SiC}$ & 1750 \\
\hline 2 & $\mathrm{SiC}$ & $\operatorname{PAN}(\mathrm{ST}-3)$ & $\begin{array}{l}\text { polysila- } \\
\text { styrene }\end{array}$ & $\beta-\mathrm{SiC}$ & 1800 \\
\hline 3 & $\mathrm{SiC}$ & PAN(HM4O) & $\begin{array}{l}\text { polysila- } \\
\text { styrene }\end{array}$ & $\beta-\mathrm{SiC}$ & 1750 \\
\hline 4 & $\mathrm{SiC}$ & PAN(HM40) & $\begin{array}{l}\text { polysila- } \\
\text { styrene }\end{array}$ & $\beta-\mathrm{SiC}$ & 1800 \\
\hline 5 & $\mathrm{SiC}$ & pitch(HM50) & $\begin{array}{l}\text { polysila- } \\
\text { styrene }\end{array}$ & $\beta-\mathrm{SiC}$ & 1750 \\
\hline 6 & $\mathrm{SiC}$ & pitch(HM50) & $\begin{array}{l}\text { polysila- } \\
\text { styrene }\end{array}$ & $\beta-\mathrm{SiC}$ & 1800 \\
\hline 7 & $\mathrm{~B}_{4} \mathrm{C}$ & PAN(HM40) & $\begin{array}{l}\text { polysila- } \\
\text { styrene }\end{array}$ & $\mathrm{B}_{4} \mathrm{C}$ & 1750 \\
\hline 8 & $\mathrm{~B}_{4} \mathrm{C}$ & PAN(HM40) & $\begin{array}{l}\text { polysila- } \\
\text { styrene }\end{array}$ & $\mathrm{B}_{4} \mathrm{C}$ & 1800 \\
\hline 9 & $\mathrm{~B}_{4} \mathrm{C}$ & pitch(HM50) & $\begin{array}{l}\text { polysila- } \\
\text { styrene }\end{array}$ & $\mathrm{B}_{4} \mathrm{C}$ & 1750 \\
\hline 10 & $\mathrm{~B}_{4} \mathrm{C}$ & pitch (HM50) & $\begin{array}{l}\text { polysila- } \\
\text { styrene }\end{array}$ & $\mathrm{B}_{4} \mathrm{C}$ & 1800 \\
\hline
\end{tabular}

\section{2-1-2 Mullite Composites}

Two kinds of continuous carbon fiber, the PAN fiber (Tohobeslon Besfight IM-400: 7 $\mu \mathrm{m}$; the structure was amorphous-like) and the pitch fiber (PETOCA HM-50: $10 \mu \mathrm{m} \phi$; the crystal structure was crystalline graphite), were used in this process. Fine powder of mullite $(0.7 \mu \mathrm{m}$; stoichiometric composition) was used as a filler. An unidirectional fiber aligned prepreg was made by the filament winding method in which a slurry was used. The slurry was consisted of filler, an organosilicon resin [ either polysilastyrene (Nihon Soda PSS-400) or polysilazane (Chisso NCP-200) ] and a toluene solvent. The prepreg was cut into segments of equal length [ $25 \mathrm{~mm}$ width and $50 \mathrm{~mm}$ length (fiber direction) ] to form post forms. The post forms were isostatically pressed and then pyrolyzed up to $700{ }^{\circ} \mathrm{C}$ in Ar atmosphere. Composite ceramics were made by the sintering (hot pressing; $330 \mathrm{~kg} / \mathrm{cm}^{2}$ ) of pyrolyzed postforms at $1600{ }^{\circ} \mathrm{C}$ or $1700^{\circ} \mathrm{C}$ in the $\mathrm{Ar}$.

\section{2-2 Characterization of Composites}

The sintering characteristics were measured in regard to the open porosity and the apparent and bulk densities, while the identification of crystal phases was done by powder X-ray diffraction, and the 
metallographic structure was observed by examining EPMA micrographs. The flexural strength [ room temperature (RT) and $1200{ }^{\circ} \mathrm{C}$ (Ar: SiC; air: mullite) ], and the fracture toughness $\left(\mathrm{K}_{10}\right)$ were measured examining a sample whose size was $3 \times 4 \times 40 \mathrm{~mm}^{3}$ (the load was applied perpendicular to the fiber axis; the flexural strength: 3 points bending; $\mathrm{K}_{10}$ : Single edge notched beam method by 3 points bending).

\section{Results and Discussion}

\section{3-1. $\mathrm{SiC}$ and $\mathrm{B}_{4} \mathrm{C}$ Composites}

\section{3-1-1. The Crystal phases in the Composites}

The identification of crystal phases in the composites detected by X-ray diffraction is shown in Table 2 . In the case of $\mathrm{SiC}$ composites, when PAN fibers were used, a
B-SiC crystal phase and an amorphous-like graphite phase were detected (sample No 1-4 in Table 2) but when pitch fiber was used a $\beta$-SiC crystal phase and a crystalline graphite phase were detected (No 5 and 6). In the case when PAN fibers were used, few differences existed in the graphite diffraction pattern between the as received fibers (ST-3 or HM4O) and the composites (as to diffraction angle, and width of the half hight in diffraction peaks; Note 1 in the Table II). In the case of the pitch fiber, the width of the half hight in the (002) diffraction peak of the graphite pattern in each composite became large than that of the as received fiber (HM50), suggesting the deterioration of the crystallinity of the graphite (Note 2 in the Table 2 ).

Table II Crystal Phases in the Ceramic Composites Detected by the Powder X-ray Diffraction

\begin{tabular}{|c|c|c|c|c|}
\hline Sample No & Filler & Fiber & Detected crystal phase & Note \\
\hline 1,2 & $\beta-\mathrm{SiC}$ & $\operatorname{PAN}(\mathrm{ST}-3)$ & $\beta-\mathrm{SiC}, \mathrm{C}$ & 1 \\
\hline 3,4 & $\beta-\mathrm{SiC}$ & PAN(HM40) & $\beta-\mathrm{SiC}, \mathrm{C}$ & 1 \\
\hline 5,6 & $\beta-\mathrm{SiC}$ & pitch(HM50) & $\beta-\mathrm{SiC}, \mathrm{C \#}$ & 2 \\
\hline 7,8 & $\mathrm{~B}_{4} \mathrm{C}$ & PAN(HM40) & $\mathrm{B}_{4} \mathrm{C}, \mathrm{C} \#, \quad \beta-\mathrm{SiC}, \quad \alpha-\mathrm{AlB}_{12}$ & 3 \\
\hline 9,10 & $\mathrm{~B}_{4} \mathrm{C}$ & pitch(HM50) & $\mathrm{B}_{4} \mathrm{C}, \mathrm{C} \#, \quad \beta-\mathrm{SiC}, \alpha-\mathrm{AlB}_{12}$ & 4 \\
\hline
\end{tabular}

C: Graphite (broad peak: i.e. like amorphous phase)

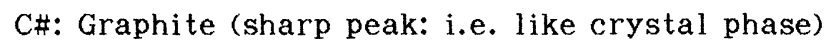

Note $1-4$ are in the text

In the case of $\mathrm{B}_{4} \mathrm{C}$ composites, $\beta$-SiC and $\alpha-\mathrm{AlB}_{12}$ diffraction patterns were observed in addition to $\mathrm{B}_{4} \mathrm{C}$ and crystalline graphite ones. In the case of PAN fiber, the shape of the (002) diffraction peak in the graphite pattern in the composite became sharper than that of the PAN fiber (HM40), suggesting the progrresive crystallization of the graphite(Note 3 in the Table 2). However, in the case of pitch fiber, few difference existed in the shape of graphite diffraction pattern between the as received pitch fiber(HM50) and the composite (Note 4 in the
Table 2).

\section{3-1-2 Metallographic structure in the composites}

Fig. 1 shows SEM micrographs of the planes parallel to the fiber axis in $\mathrm{SiC}$ composites. In these micrographs cracks were observed perpendicular to the fiber asix [ the cracks could have arisen from a thermal expansion mismatch between the fibers and the matrix ( $\alpha$ (axial direction of fiber) = $\left.\left.-1 \times 10^{-\sigma} / \mathrm{deg} ; \alpha(\mathrm{SiC})=5.7 \times 10^{-\mathrm{e}} / \mathrm{deg}\right)\right]$. 


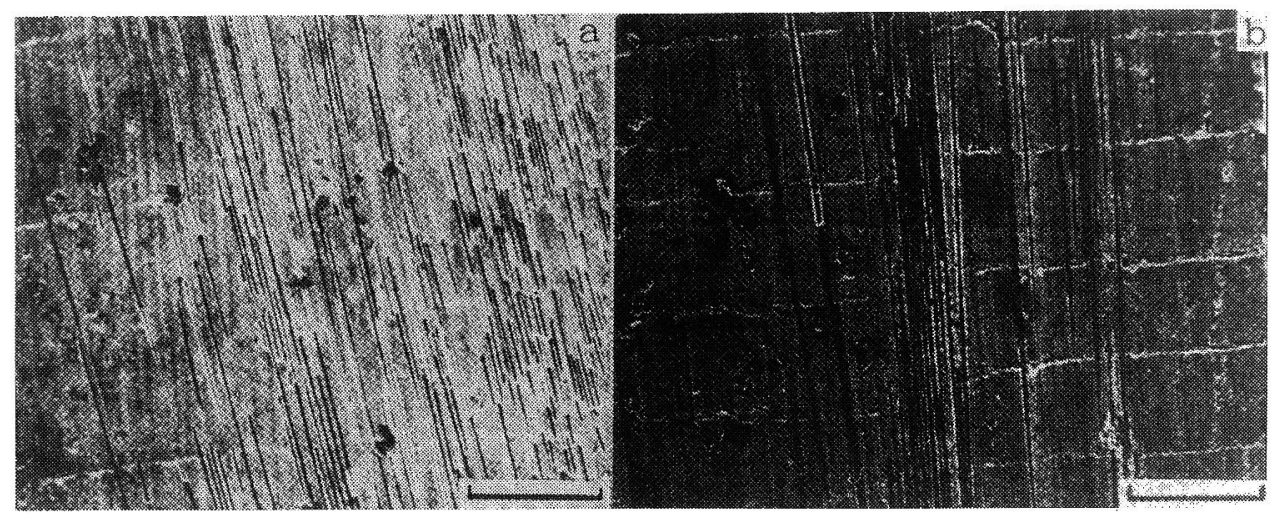

Fig.1 - SEM micrographs of the planes parallel to the fiber axis in SiC composites. (a): PAN (ST-3) fiber, (b): pitch (HM50) fiber. The markers in the micrographs correspond to $200 \mu \mathrm{m}$.

Similar cracks were observed in the $\mathrm{SiC}(10)$ and the carbon (9) fiber reinforced mullite composites. In the case of the pitch fiber (HM50), major cracks were observed (Fig. 1-(b): sample No 5 ) but minor ones in the case of the PAN fiber ( ST-3; Fig. 1-(a): sample No 1 ). In the micrograph of the composite contained PAN(HM40) fiber, the frequency of the crack was half way between the two other cases. Since the bonding between the pitch fibers(HM50) and the matrix seemed to be tight, the thermal stresses between the fibers and the matrix were difficult to accommodate. However, the bonding between the PAN(ST-3) fiber and the matrix seemed to be loose thus the thermal stresses might have been accommodated.
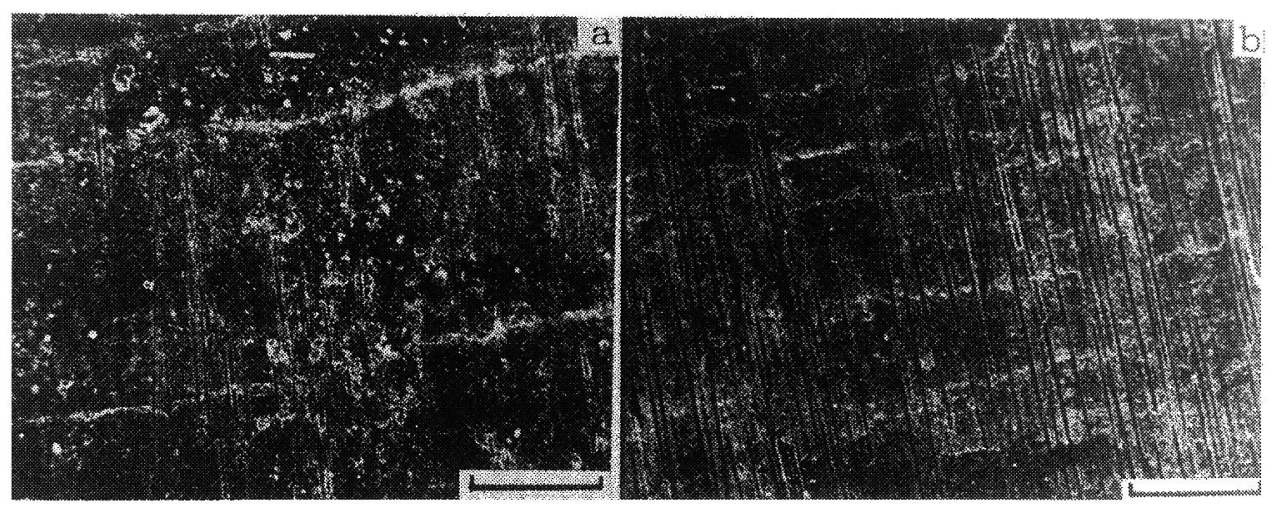

Fig.2 - SEM micrographs of the planes parallel to the fiber axis in $\mathrm{B}_{4} \mathrm{C}$ composites. (a): PAN (HM40) fiber, (b): pitch (HM50) fiber. The markers in the micrographs correspond to $200 \mu \mathrm{m}$.

Fig. 2 shows SEM micrographs of the planes parallel to the fiber axis in $\mathrm{B}_{4} \mathrm{C}$ composites. In these micrographs cracks were observed perpendicular to the fiber axis 
similar to the case of SiC composites (Fig. 1). These cracks were more evident in the PAN fiber content composite (Fig. 2-(a): sample No.8) than in the pitch fiber content one ( (Fig. 2-(b): sample No 10). This might be attributed to the possibility that in the former case the bonding between the fibers and the matrix were tight compared to the latter.

\section{3-1-3 Mechanical properties of the composites}

Table 3 shows the flexural strength and the fractural toughness of the composites. In the case of $\mathrm{SiC}$ composites, the room temperature flexural strength increased with decreasing open porosity in both fiber types. No distinct relationship was observed between the strength at room temperature and the strength at $1200{ }^{\circ} \mathrm{C}$ in each sample. The room temperature strength of the sample fabricated at the same hot pressing temperature decreased following the order from highest to lowest of PAN(ST-3) to
PAN(HM40) to pitch(HM50). This might be attributed to the fact that the pitch fiber content samples had more noticeable cracks perpendicular to the fiber axis than the PAN fiber did (Fig. 1). The fractural toughness of the PAN fiber content sample was higher than that of the pitch fiber content sample. And an evident fiber pull-out was observed in the PAN fiber content composites (Fig. 4-(a)).

In the case of $\mathrm{B}_{4} \mathrm{C}$ composites, the flexural strength of the pitch fiber content samples were higher than those of the PAN fiber content ones. This might be attributed that the PAN fiber content samples had the major cracks perpendicular to the fiber axis while the pitch fiber content samples had only minor cracks (Fig. 2). The fractural toughness of the pitch fiber content samples was higher than that of the PAN fiber content ones, which might be closely related to the fact that the bonding between the fibers and the matrix in the pitch fiber content samples seemed loose compared to those in the PAN fiber content ones.

Table 3. Flexural Strength and Fracture Toughness of the Composites

\begin{tabular}{cclcccc}
\hline Sample No & Matrix & Fiber & $\begin{array}{c}\text { Open porosity } \\
(\%) \#\end{array}$ & $\begin{array}{c}\text { Flexural } \\
(\text { MPa }) * \\
\mathrm{RT}\end{array}$ & $\begin{array}{c}\text { strength } \\
1200 \mathrm{C}(\mathrm{Ar})\end{array}$ & $\begin{array}{c}\mathrm{K} 1 \mathrm{MPa} \\
(\mathrm{m}) *\end{array}$ \\
\hline 1 & $\mathrm{SiC}$ & PAN(ST-3) & 8.0 & 529.6 & & 15.4 \\
2 & $\mathrm{SiC}$ & PAN(ST-3) & 6.7 & 599.2 & 511.9 & 15.4 \\
3 & $\mathrm{SiC}$ & PAN(HM40) & 11.5 & 264.8 & & 16.1 \\
4 & $\mathrm{SiC}$ & PAN(HM40) & 10.1 & 384.4 & 378.5 & 16.9 \\
5 & $\mathrm{SiC}$ & pitch(HM50) & 8.8 & 215.7 & & 10.3 \\
6 & $\mathrm{SiC}$ & pitch(HM50) & 6.1 & 276.5 & 375.6 & 9.9 \\
7 & $\mathrm{~B} 4 \mathrm{C}$ & PAN(HM40) & 6.3 & 206.4 & & 4.0 \\
8 & $\mathrm{~B} 4 \mathrm{C}$ & PAN(HM40) & 4.3 & 206.4 & & 4.5 \\
9 & $\mathrm{~B} 4 \mathrm{C}$ & pitch(HM50) & 5.0 & 375.2 & & 7.3 \\
10 & $\mathrm{~B} 4 \mathrm{C}$ & pitch(HM50) & 4.4 & 393.2 & & 6.2 \\
\hline
\end{tabular}

An error in each value is within $3 \%(\#)$ and $10 \%(*)$

Fig. 3 shows the stress - displacement (SD) traces of the $\mathrm{SiC}$ and $\mathrm{B}_{4} \mathrm{C}$ composites under the bending test. In the PAN(HM40) fiber reinforced $\mathrm{SiC}$ sample, the SD trace displayed a slight arc up to the maximum stress value ( (a) trace in Fig. 3 ), whereas in the pitch (HM50) fiber reinforced $\mathrm{B}_{4} \mathrm{C}$ sample, the SD trace was relatively linear most of the way up to the maximum stress value ( (b) trace in Fig. 3 ). These phenomena would reflect the tightness of the bondings between fibers and matrix and the rigidity of the matrix. 


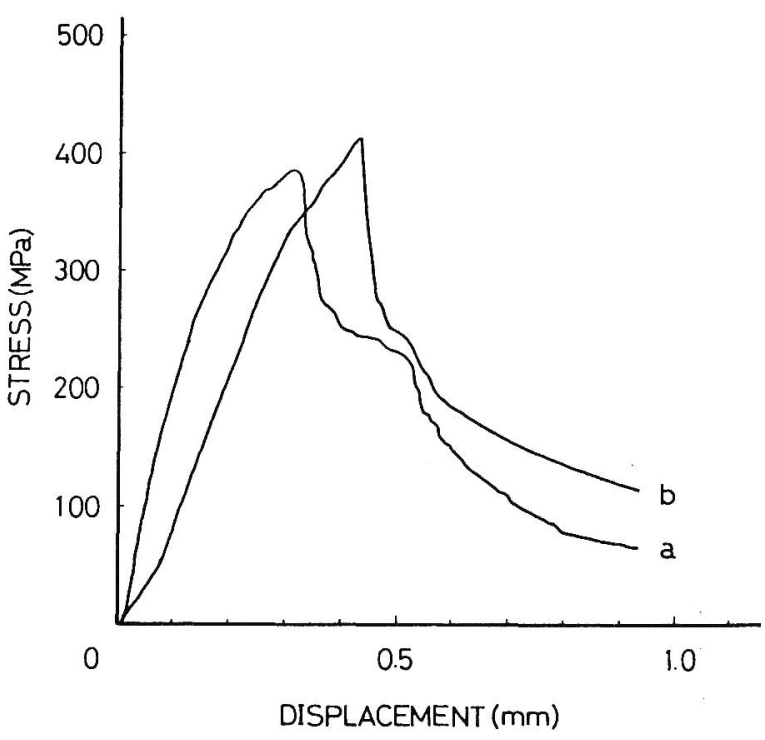

Fig. 3 - Stress - displacement traces of SiC and $\mathrm{B}_{4} \mathrm{C}$ composites under the bending test. a: PAN(HM40) fiber/SiC, b: pitch(HM50) fiber $/ \mathrm{B}_{4} \mathrm{C}$.

Fig. 4 shows the SEM micrographs of the fiber pull-out of the fractured surfaces in the PAN (ST-3) and pitch (HM50) fiber reinforced SiC samples.

In the case of the PAN fiber (Fig. 4(a) ), a major fiber pull-out was observed, whereas in the case of the pitch fiber (Fig. 4 (b) ), the fiber pull-out was minor. The above evidence is related to the nature of the cracks which were observed perpendicular to the fiber axis (Fig. 1): i.e. the sample which revealed a major fiber pull-out (Fig. 4-(a) ) had the minor cracks [Fig. 1-(a) ], and the sample which reveald a minor fiber pull-out ( Fig. 4-(b) ) had the predominant cracks ( Fig. 1-(b) ). A similar relationship was observed in the PAN (HM40) and the pitch (HM50) fiber reinforced $\mathrm{B}_{4} \mathrm{C}$ samples. The PAN fiber reinforced $\mathrm{B}_{4} \mathrm{C}$ sample revealed minor fiber pull-out, and major cracks (Fig. 2-(a) ). Cotrary to this, the pitch fiber reinforced sample reveraled major fiber pull-out, and minor cracks ( Fig. 2-(b) ).
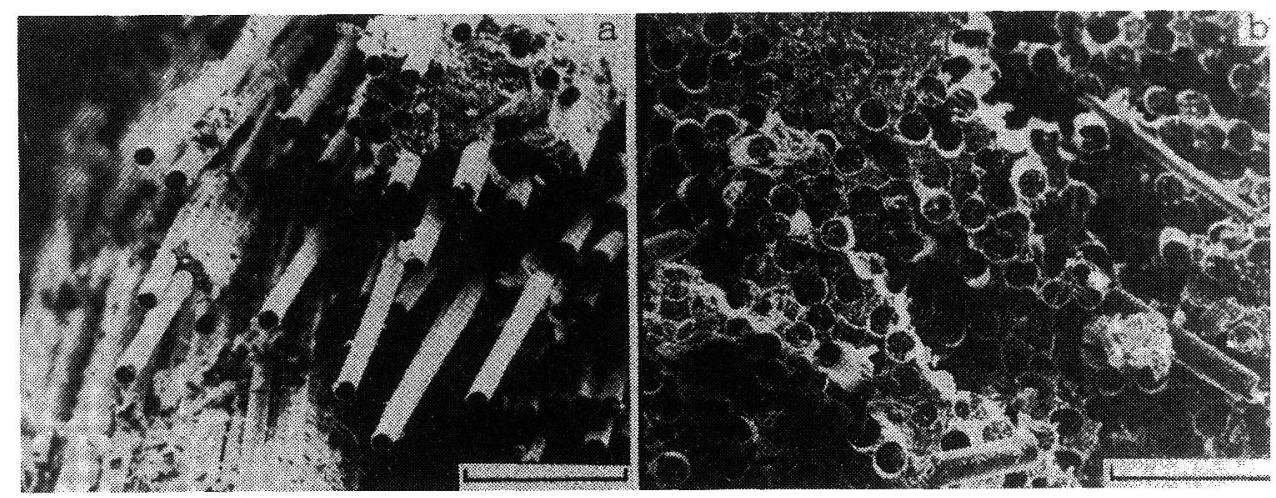

Fig.4 - SEM micrographs of the fiber pull-out of fractured surfaces of SiC composites. (a): PAN (ST-3) fiber, (b): pitch (HM50) fiber. The markers in the micrographs correspond to $50 \mathrm{\mu m}$.

\section{3-2. Mullite Composites}

3-2-1 Sintering characteristics, crystal phases, and metallurgical structures
The sintering characteristics of the composites are shown in Table 4 . 
Table 4. Sintering characteristics of the composites

\begin{tabular}{lccccc}
\hline Resin & Fiber & $\begin{array}{c}\text { Hot pressing } \\
\text { temperature } \\
\left({ }^{\circ} \mathrm{C}\right)\end{array}$ & $\begin{array}{c}\text { Open porosity } \\
(\%)\end{array}$ & $\begin{array}{c}\text { Apparent } \\
\text { density } \\
\left(\mathrm{g} / \mathrm{cm}^{3}\right)\end{array}$ & $\begin{array}{l}\text { Bulk } \\
\text { density } \\
\left(\mathrm{g} / \mathrm{cm}^{3}\right)\end{array}$ \\
\hline Polysilastyrene & PAN & 1600 & 7.80 & 2.63 & 2.12 \\
Polysilastyrene & PAN & 1700 & 10.70 & 2.57 & 2.30 \\
Polysilastyrene & pitch & 1600 & 16.70 & 2.78 & 2.31 \\
Polysilastyrene & pitch & 1700 & 7.80 & 2.83 & 2.35 \\
Polysilazane & PAN & 1600 & 2.16 & 2.54 & 2.48 \\
Polysilazane & PAN & 1700 & 2.80 & 2.57 & 2.50 \\
Polysilazane & pitch & 1600 & 2.75 & 2.60 & 2.47 \\
Polysilazane & pitch & 1700 & 2.40 & 2.62 & 2.56 \\
\hline
\end{tabular}

An error in each value is within $3 \%$.

In the case of the composite by using polysilazane the open porosity was much lower than that of the composite using polysilastyrene in regard to each fiber and at each hot pressing temperature.

The identification of crystal phases in the composites detected by X-ray diffraction is shown in Table 5 .

Table 5. Crystal phases in the composites detected by the powder X-ray diffraction

\begin{tabular}{|c|c|c|c|}
\hline Resin & Fiber & $\begin{array}{l}\text { Hot pressing } \\
\text { temperature } \\
\left({ }^{\circ} \mathrm{C}\right)\end{array}$ & Crystal phase \\
\hline $\begin{array}{l}\text { Polysila- } \\
\text { styrene }\end{array}$ & PAN & 1600 & $3 \mathrm{Al}_{2} \mathrm{O}_{3} 2 \mathrm{SiO}_{2}, \mathrm{C}$ \\
\hline $\begin{array}{l}\text { Polysila- } \\
\text { styrene }\end{array}$ & PAN & 1700 & $3 \mathrm{Al}_{2} \mathrm{O}_{3} 2 \mathrm{SiO}_{2}, \mathrm{Al}_{2} \mathrm{O}_{3}, \mathrm{SiC}, \mathrm{C}$ \\
\hline $\begin{array}{l}\text { Polysila- } \\
\text { styrene }\end{array}$ & pitch & 1600 & $3 \mathrm{Al}_{2} \mathrm{O}_{3} 2 \mathrm{SiO}_{2}, \mathrm{C} *, \mathrm{SiC}$ \\
\hline $\begin{array}{l}\text { Polysila- } \\
\text { zane }\end{array}$ & PAN & 1700 & $3 \mathrm{Al}_{2} \mathrm{O}_{3} 2 \mathrm{SiO}_{2}$, Sialon\#, $\mathrm{Al}_{2} \mathrm{O}_{3}, \beta-\mathrm{Si}_{3} \mathrm{~N}_{4}, \mathrm{C}$ \\
\hline $\begin{array}{l}\text { Polysila- } \\
\text { zane }\end{array}$ & pitch & 1600 & $3 \mathrm{Al}_{2} \mathrm{O}_{3} 2 \mathrm{SiO}_{2}$, Sialon\#, $\mathrm{C} *$ \\
\hline $\begin{array}{l}\text { Polysila- } \\
\text { Zane }\end{array}$ & pitch & 1700 & $3 \mathrm{Al}_{2} \mathrm{O}_{3} 2 \mathrm{SiO}_{z}$, Sialon\#, C* \\
\hline
\end{tabular}

C : graphite (broad pattern: i.e, like amorphous phase)

C* : graphite (sharp pattern: i.e. like crystal phase)

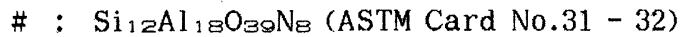

In the case of the composites fabricated by using polysilastyrene and hot pressing at $1600{ }^{\circ} \mathrm{C}, 3 \mathrm{Al}_{2} \mathrm{O}_{3} 2 \mathrm{SiO}_{2}$ crystal, amorphous-like or crystalline graphites and $\mathrm{SiC}$ phases were detected, while hot pressing at $1700{ }^{\circ} \mathrm{C}$, in addition to these phases, $\mathrm{Al}_{2} \mathrm{O}_{3}$ crystal phase was detected. However, in the composites by using polysilazane, a considerable sialon phase $\left(\mathrm{Si}_{12 \mathrm{~A}} \mathrm{~A}_{18 \mathrm{O}_{39} \mathrm{~N}_{8}}\right.$ ) was detected in addition to the mullite, $\beta-\mathrm{Si}_{3} \mathrm{~N}_{4}$ and the amorphous-like or crystalline graphites phases. It can be presumed that the pyrolyzation of the moisture absorbing polysilazane forms $\mathrm{Si}_{3} \mathrm{~N}_{4}, \mathrm{Si}_{2} \mathrm{ON}_{2}$ and $\mathrm{SiC}$. 
Evidently either $\mathrm{Si}_{3} \mathrm{~N}_{4}$ or $\mathrm{Si}_{2} \mathrm{ON}_{2}$ reacts with the mullite filler forming the Sialon phase. In the case when using polysilazane, PAN fiber and hot pressing at $1700^{\circ} \mathrm{C}$, an appreciable $\mathrm{Al}_{2} \mathrm{O}_{3}$ phases was detected as was the case with polysilastyrene use under same conditions.

In Figs. 5-(a) and 6-(a), showing back scattered electron image, the matrixes were densely packed in the interstices of fibers. No cracks, which would presumably arise from a mismatch between therma] expansion coefficient of matrix $[\alpha$ (mullite $) \simeq 4.5 \mathrm{x}$ $\left.10^{-\infty} /{ }^{\circ} \mathrm{C}\right]$ and that of the radial direction of carbon fiber, were observed around fibers. The Vf of the composites was estimated to be around $35 \%$. In the case of PAN fiber, $\mathrm{Al}$ and $\mathrm{Si}$ atoms diffused far inside the fibers as were observed in Figs. 5-(b) and $-(c)$, while in the case of pitch fiber they diffuse around peripheries of fibers (Figs. 6-(b) and -(c)) ) .
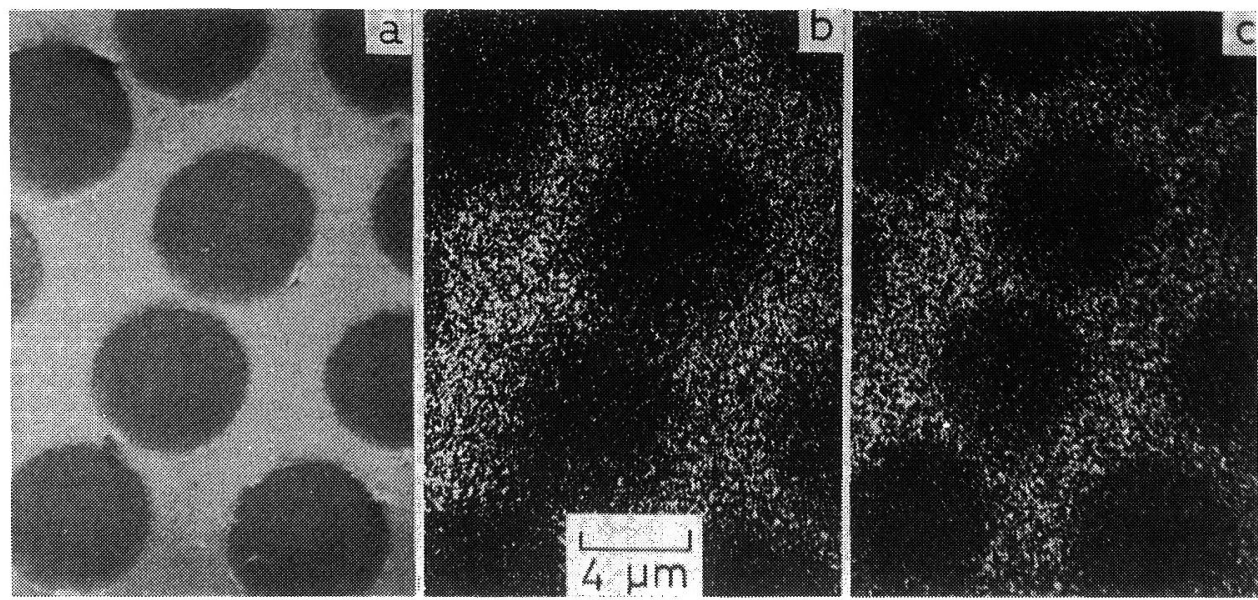

Fig.5 EPMA micrographs of plane perpendicular to the fiber axis

(Sample was fabricated by using polysilazane, PAN fiber and hot pressing at $1700{ }^{\circ} \mathrm{C}$.) (a): back scattered electron image, (b): AlK $\alpha$ image, (c): SiK $\alpha$ image
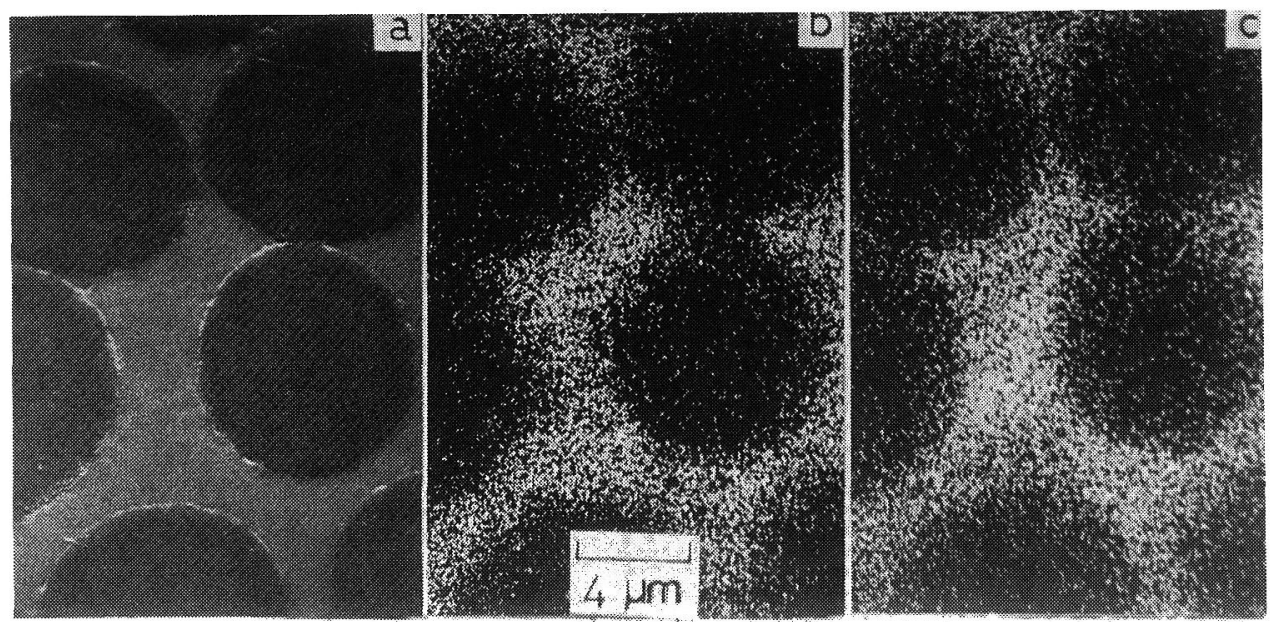

Fig. 6 EPMA micrographs of plane perpendicular to the fiber axis

(Sample was fabricated by using polysilazane, pitch fiber and hot pressing at $1700^{\circ} \mathrm{C}$.) (a): back scattered electron image, (b): AlK $\alpha$ image, (c): SiK $\alpha$ image 
In the case when using the PAN fiber, many cracks were observed perpendicular to the fiber axis (in the SEM micrograph taken to the plane parallel to the fiber axis). Similar cracks were reported in the case of $\mathrm{SiC}$ monofilament reinforced mullite composites 10). However, in the case of pitch fiber few crack was observed. In the case of PAN fiber, a thermal stress along the fiber axis, arising from a thermal expansion mismatch $[\alpha$ (carbon fiber; axial direction $\left.) \simeq-0.1 \times 10^{-8} /{ }^{\circ} \mathrm{C}\right]$, can be severe because of tight binding between the matrix and fiber (Fig. 5). Contrary to this, in the case of pitch fiber, the thermal stress can be accomodated to some extent because of loosening between the matrix and fiber [ components of the matrix diffuse around peripheries of the pitch fibers, so the bondings between fibers and matrix are weak (Fig. 6). ]

\section{3-2-2 Mechanical properties}

Table 6 shows the flexural strength and the fracture toughness of the composites. In the composites, when using the same resin type and fiber type, both the room temperature strength and fracture toughness of the samples fabricated by hot pressing at $1700{ }^{\circ} \mathrm{C}$ tended to have higher values than the samples fabricated by hot pressing at $1600{ }^{\circ} \mathrm{C}$. Both the room and high temperature strengths of the samples fabricated by using polysilazane tended to have higher values than those fabricated by using polysilastyrene, in the same fiber type.

Table 6. Flexural strength and fracture toughness of the composites

\begin{tabular}{|c|c|c|c|c|c|c|c|c|c|}
\hline \multicolumn{2}{|c|}{ Resin } & \multicolumn{3}{c|}{ Polysilastyrene } & \multicolumn{3}{c|}{ Polysilazane } \\
\hline \multicolumn{2}{|c|}{ Fiber } & \multicolumn{2}{c|}{ PAN } & \multicolumn{2}{c|}{ pitch } & \multicolumn{3}{c|}{ PAN } & \multicolumn{2}{c|}{ pitch } \\
\hline Hot pressing temperature ( $\mathrm{C}$ ) & 1600 & 1700 & 1600 & 1700 & 1600 & 1700 & 1600 & 1700 \\
\hline $\begin{array}{c}\text { Flexural } \\
\text { strength } \\
\text { (MPa) }\end{array}$ & R.T. & 429 & 474 & 413 & 490 & 846 & 507 & 407 & 610 \\
\hline \multirow{2}{\mathrm{K}_{1\mathrm{C}}}{} & $1200^{\circ} \mathrm{C}$ (air) & 492 & 211 & 433 & 567 & 827 & 93 & 518 & 882 \\
\hline (MPa $\sqrt{\mathrm{m}})$ & R.T. & 16.4 & 19.3 & 14.5 & 16.3 & 16.6 & 19.3 & 13.2 & 17.7 \\
\hline
\end{tabular}

An error in each value is within $10 \%$

The reason for these results has not yet been discerned, however, it might relate to the fact that the former samples had a sialon phase (Table 5) and the lower open porosities (Table 4). The strength and fracture toughness at high temperature tended to have higher values than those at room temperature. This tendency was dominant in the case of pitch fiber use. This can be attributed to the fact that (a) the matrixes of the composites become soft at high temperature, which disturbs crack propagation, and that (b) the PAN fibers deteriorate more than the pitch fibers during the composite fabrication process at high temperature thereby decreasing the reinforcement of the composites.

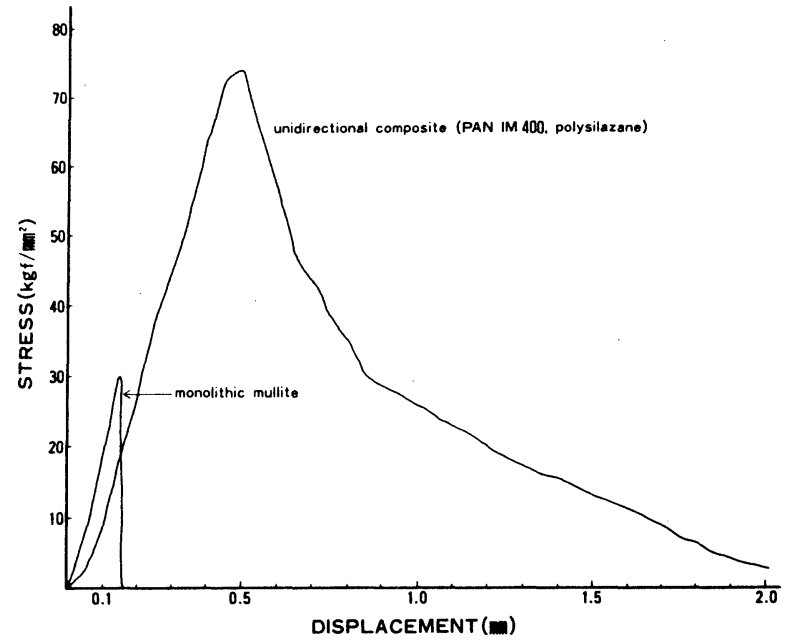

Fig. 7 Stress-displacement curves of monolithic and composite mullites 
Fig. 7 shows stress-displacement curves of monolithic and composite mullite in the flexural tests.

The monolithic mullite showed linear stress-displacement curve, which was commonly observed in brittle ceramics, and the stress suddenly dropped to zero after the break point. However, the composite showed almost linear curve up to the break point, and then the stress gradually decreased corresponding to the amount of fiber breaking or crack growth. The flexural strength of the composite was much higher than that of monolithic mullite, owing to the carbon fiber reinforcement. The displacement of the composite at the break point was much larger than that of monolithic mullite.

In the composites fabricated by using pitch fibers, the predominant fiber pull-out was observed compared to those fabricated by using PAN fibers. This was closely related to the fact that the components of matrix diffuse only on the periphery of the pitch fibers (Fig. 6).

\section{Conclusion}

$\mathrm{SiC}, \mathrm{B}_{4} \mathrm{C}$, and mullite composites reinforced with PAN and pitch carbon fibers were fabricated by using the slurry process which employed organosilicon resin followed by hot pressing.

The room temperature flexural strength and fractural toughness of the PAN fiber reinforced $\mathrm{SiC}$ composites were higher than those of the pitch fiber reinforced ones. This was closely related the fact that the PAN fiber reinforced composites had minor as-fabricated cracks and remarkable fiber pull out than the pitch fiber composites did.

The pitch fiber reinforced $\mathrm{B}_{4} \mathrm{C}$ composites had higher flexural strength and fractural toughness compared to those of the PAN fiber ones, which was closely related the fact that the pitch fiber composites had minor as-fabricated cracks and remarkable fiber pull-out than the PAN fiber composites did.
The mullite composites fabricated by using polysilazane had a trend to have higher flexural strengths than those fabricated by using polysilastyrene.

The mullite composites fabricated by using the pitch fiber revealed dominant fiber pull-out on the fracture test.

\section{References}

1) E. Fitzer and R. Gadow, American Ceramic Society Bulletin, 65 (2) (1986), 326-335.

2) A. J. Caputo et al., American Ceramic Society Bulletin, 66 (2) (1987), 368-372.

3) P. J. Lamiq et al., American Ceramic Society Bulletin, 65 (2) (1989), 336-338.

4 ) H. Hannache, J. M. Quenisset, and R. Naslain, Journal of Materials Science, 19 (1984), 202-212.

$5)$ K. M. Prewo, J. J. Brennan, and G. K. Lyden, American Ceramic Society Bulletin, 65 (2) (1986), 305-322.

6) J. K. Guo et al., Journal of Materials Science, 17 (1982), 3611-3616.

7 ) K. Nakano et al., SINTERING '87 (Elsevier Applied Science, 1988). 1350.

8 ) K. Nakano et al., DEVELOPMENTS IN THE SCIENCE AND TECHNOLOGY OF COMPOSITE MATERIALS (Elsevier Applied Science, 1989). 381.

9) K. Nakano et al., "Fabrication of Fiber Reinforced Mullite Composites" (Paper presented at the First Japan International SAMPE Symposium, Chiba, Japan, 29 November 1989).

10) R. N. Singh and A. R. Gaddipati, Journal of the Americal Ceramic Society, 71 (2) (1988), C100-C103. 